\title{
DO GOVERNMENT LOANS CAUSE INFLATION?
}

\author{
By Jacor H. Hollander, Ph.D.,
}

Professor of Political Economy, The Johns Hopkins University.

In the cynicism born of world collapse, George Brandes has lately revived an epigram imputed to Frederick the Great: "I begin by taking. Then I always find men of science to prove the justice of my claim." There is danger of scholarship becoming thus "official" in a democracy no less than in an absolutism. Public passion cracks as sharp a whip as any despot, and the applause of the market-place is as grave a menace to independent thought as the favor of the throne.

In public finance, war or peace, the treasury is always beset by two opposed forces. On the one hand, there is opportunism and practicability - opportunism in using the stress of war need to accomplish ends in doubt; practicability in meeting the fiscal strain with least trouble and dislike. On the other hand is economic theory and fiscal law-rugged and dure, straight and narrow, serving the public need with measures conceived solely with respect to fiscal principle, and hewing to this line even with struggle in making and difficulty in carrying out.

Certainly no budget has ever been wholly the one thing or the other-utterly neutral in convenience nor wholly virginal in theory. Even a time-serving finance minister must occasionally relapse into science without knowing it, and the scholar enthroned in the exchequer cannot have all literally as his text-books set forth. But the varying degree of emphasis is sufficient difference. In the one case convenience is the end in view with theoretical excellence a by-product; in the other, fiscal theory holds mitigated by practical concession.

The rôle of the student critic called to pass judgment upon these alternate policies is at least in one respect plain. He should insist that each policy stand firmly on its own merit, and that if non-fiscal considerations are to affect the course this should be clearly set forth. Most of all, should he resent the use of bad scientific reasoning in praise of one procedure or in blame of the other. 
A glaring instance of this misuse is the outright resistance to funding in war finance on the score that it makes inevitably for inflation and thus for high prices - or more briefly the inflation argument against war loans. Both as a melancholy example of scientific lapse, and as a mischief-making error in the actual conduct of war finance, it has seemed worth while to examine this claim.

It is possible to trace with some exactness the growth of the doctrine. Without returning to shadowy beginnings, the first explicit phrasing of the argument appears to have been made in 19151916 by an English economist of note, Mr. A. C. Pigou, professor of political economy in the University of Cambridge in two public lectures delivered in Cambridge, in articles contributed to the Contemporary Review and, more formally, in a little book on "The Economy and Finance of the War."

The preface of Pigou's book is dated October, 1916. In December, 1916, at the meeting of the American Economic Association held in Columbus, Ohio, an eminent American economist, Professor O. M. W. Sprague of Harvard University, presented a paper on "Loans and Taxes in War Finance" wherein, quite independent of Pigou's exposition, the inflationist argument against funding, foreshadowed in certain of the speaker's earlier writings, was set forth with detail and vigor. Admitting that "it is not absolutely inevitable that war finance based on borrowing should cause a general rise in prices," Professor Sprague noted that "It is significant, however, that whenever governments have resorted to this policy prices generally have manifested marked and continued upward tendency."

Professor Pigou's and Professor Sprague's views, spoken with some measure of scientific restraint, were received with attention, if not assent, within expert circles. They were given circulation and vogue by the Minnesota "memorial of American economists to Congress regarding war finance," an attempt to determine congressional action upon the then pending war revenue bill by arraying the body of academic economists in support of such propositions as:

It may be necessary for a month or two at the outset to issue a limited amount of bonds, pending the collection of increased taxes, but beyond these, which might well be made repayable within a year, no necessity for bonds exists.

Thus far the inflationist doctrine had circulated as an academic hypothesis. In April, 1917, it was unexpectedly translated into the 
higher altitude of state policy by a sentence of President Wilson's message to the special session of Congress:

It is our duty, I most respectfully urge, to protect our people so far as we may against the very serious hardships and evils which would be likely to arise out of the inflation which would be produced by vast loans.

\section{II}

The inflationist argument has been too often set forth to need restatement here. Its drift will be recalled by the summary of a competent student, Professor Sprague:

Many subscribers [to the loans] borrow from the banks the funds required to meet their commitments, pledging other property and even the war loan itself. The banks adopt a liberal patriotic loan policy and also subscribe largely on their own account. These transactions, the borrowing from banks and the investments by banks, occasion expansion in the volume of credit, both in the form of bank notes and of deposits, and are the most potent single cause of the general advance in prices during periods of war.

If we follow the first impulse of the scientist and turn from outright hypothesis to attempted proof, the inflationist contention encounters rough sledding. No one has to my knowledge suggested that verification be found in past war financing, nor is there likely to be such claim. For even remotely parallel conditions we should be obliged to turn to the two great wars of the past hundred years-the Napoleonic struggle and our own Civil War-and here the relative crudity of banking operations in the one case and the all-eclipsing effect of fiat issues in the other put any kind of helpful comparison out of question. Such warrant as may be found for the doctrine is to be sought in the fiscal developments of the past three years--in the longer experience of Great Britain, in the more recent history of the United States.

As far as Great Britain is concerned, there has been an extraordinary rise in general prices and there have been extensive funding operations. The Economist index number which in August, 1914, stood at 2698 had risen in August, 1915, to 3296, in August, 1916, to 4372 , and in August, 1917, to 5658-a relative change of 110 per cent. As to funding operations, the net borrowings including loans to allies and dominions, from August 1, 1914, to August 25, 1917, were roughly twenty billion dollars as compared with somewhat more than six billion dollars raised by revenue. 
But the English situation has been affected by the issue of treasury notes "to a much greater extent than was required to take the place of the gold which has been called in from circulation" and by a great increase in the coinage of silver. Moreover, English borrowings are an intricate complex of war loans, treasury bills, exchequer bonds, war savings certificates and bank credits against ways and means advances.

During the past months there has raged in English financial circles, technical and academic, a controversy recalling in variety and intensity the classic bullion debate of a century ago, as to whether inflation really existed in England, whether it was imputable, wholly or in any part, to public borrowing, and whether this consequence, if existent, was avoidable or inevitable. The result has been, if not to leave the main issue in doubt, at least to make it impossible in our present knowledge to determine the respective contribution of the several factors involved.

In the United States we have witnessed a hardly less sensational rise in prices, the Department of Labor index number of wholesale prices standing at 100 in 1916 as compared with 81 in 1915 and 80 in 1914 and advancing thereafter to 139 in April, 1917. But during this period the country was still in neutral state, and there was no resort to large scale borrowing. There were extensive purchases of obligations of foreign governments; but these were not remotely in excess of the new domestic capital issues that more normal conditions might have been expected to induce. If any closer connection between funding and inflation be sought, it appears that the period of war loans, dating from the first liberty loan, was a period of continuing rising prices, the Department of Labor index number of wholesale prices advancing from 139 in April, to 149 in May, to 150 in June; but that the percentage of increase was not sensationally more rapid than in the preceding period.

Returning then from unsuccessful induction to cautious analysis, it appears that inflation may conceivably but need not inevitably result from funding operations. The actual process has been subject to searching examination by Professor William A. Scott, and the conclusions therein reached are likely to represent the present consensus of deliberate economic opinion: To the extent that bonds are bought, ultimately, from uninvested capital, from current income, from liquidated investments, or from future savings there can be no 
inflation. To the extent that bonds are bought by banks for their own account by credit creation, or by individuals through bank loans or are thereafter hypothecated for such loans, and partake of the nature of long time engagements rather than of installment purchases-inflation may result. The actual proportion of such non-inflating "savings" purchases to the class of potentially inflating "credit" purchases is, in the war-funding experience of the United States, undetermined. But whatever it be, there is no fixity attached thereto and financial policy exercised through banking control can reduce to the degree of virtual elimination the relative and even the absolute importance of credit purchases.

In the far less guarded form in which it has circulated in the United States, the inflation argument represents not the use of wrong theory, but the abuse of a right one. It is reminiscent of Elia's injunction to eschew roast pig lest conflagrations be encouraged, or a later counsel to travel on foot because badly driven horses will sometimes shy. That an unwisely directed borrowing policy may take the form of "credit" loans rather than of "savings" loans is no reason why borrowing as a measure of war finance should be denounced lock, stock and barrel as inflationist in effect. The obvious alternative is, having first determined to what extent recourse shall or must be had to loans in a war programme, to plan such operations to tap the fund of present and the source of future savings.

\section{III}

The inflationist controversy, aside from the rather sorry rôle which expert economic opinion has played therein, points two lessons: (1) The danger of belaboring loans as an unsound method of war finance in view of the fiscal validity or, waiving any discussion, the practical necessity of recourse thereto. (2) The importance in a funding policy of distinguishing between "credit" loans and "savings" loans, of stimulating "savings" loans by appropriate devices, and of discouraging large resort to "credit" loans.

As to the first: The inflationist argument may conceivably have served some purpose in dispelling the illusion that the war could be financed without material increase in taxation. By specifying and emphasizing a danger that attends funding, the public mind may have become reconciled to new and drastic tax 
burdens. But a disingenuous logic will inevitably rise to plague the state that uses it, in finance as in legislation.

Is it fanciful to assume that some considerable part of the difficulty we have experienced in arousing the great body of American citizens to the life and death necessity of continuous and universal loan subscription is due to the lethargy, even tacit hostility, in the public mind engendered by the denunciation of public borrowing as a vicious mode of financing the war? Such terms as "the conscription of capital," degenerating into outright epithets, such as "the slacker's theory of war finance," employed by Professor Carver, may have seemed of tactical advantage in aiding the enactment of heavy income and profits taxation. But we should impute a very short memory and a very faulty logic to the popular mind were we to assume that when, a few months later, the liberty loan campaigns were launched there was not a traceable consequence of public indifference or even indisposition.

As to the second: The importance of distinguishing between credit loans and savings loans, of discouraging the one and stimulating the other-there has been an impressive because unconscious development in the United States in even the short six months' interval between the first and the second liberty loans. We entered upon our war loan financing in much the manner of our infrequent peace loan operations, with the expectation of large corporate purchases and incidental regard to general popular absorption. We emerged from that trying experience-perhaps wiser, certainly chastened-with the realization that there was a limit marked by investment resources beyond which corporate purchases could be pushed only at the expense of credit expansion and that, on the other hand, there was a vast untouched fund in the form of the current and prospective savings of the great body of producers of the nation from which funded loans might be drawn.

The second liberty loan campaign has been waged with this distinction grown clearer and clearer. Before it had ended "save and pay" had become a slogan almost in replacement of the older "borrow and buy," and the nation may be said to have fairly awakened to the realization that the ultimate source of a national loan is the unspent income of its producers. It is an exhibit of the financial genius of the country, and a tribute to the sanity of its financial leadership that the banking organizations of the country re- 
sponded, not, it is true, with equal effectiveness but on the whole with remarkable adaptability, to this new policy.

Much too remains to be done, but the vista is far from depressing. A nation to small extent accustomed to save, and to negligent extent accustomed to place these savings in funded form, to whom a government bond has been as comprehensible but as unaccustomed an acquisition as, let us say, an aeroplane or an adding machine, has taken its first step, and a large and true one at that, in the direction in which we must learn to walk if the war is to be financed with greatest efficiency and least hardship.

In the discipline that lies ahead there must be universal part. It will not be enough to preach to the great body of wage-earners restraint in individual expenditure and diversion of income- -whether accruing from increased productivity or heightened abstinence-to the public treasury through the instrumentality of periodic funding, continuous borrowing or war savings certificates. A like denial must show itself in every quarter. Public bodies, states, counties, cities and preëminently the federal government, must postpone contemplated, even suspend actual projects of public improvement, commendable in ordinary times but now perilous in their additional requisition upon the capital supply and the labor force of the nation. Industrial and mercantile establishments, where not under the whip and spur of war production, must exercise caution in applying the gains of enterprise to enlargement of plant and join the queue of lenders. Almost all the financial institutions of the land, both by individual initiative and through centralized leadership, must embody in outright banking practice the doctrine of economic restraint.

For this is the alternative we confront: Not the fantastic possibility of financing the war without resort to loans; but the choice of a manner of borrowing on the one hand, which will supply the nation's needs from the savings of its citizenry, with a heritage of new thrift and restrained expenditure, and, on the other hand, a mode of forced loan effected through the unchecked expansion of banking credit with its mischief-making trail of inflation and depreciation. Only an unintelligent fatalism will leave the issue uncertain.

NoтE.-Since the foregoing was written, there have been im- 
portant developments in our financial policy. The Treasury has made large use of certificates of indebtedness in anticipation of revenue from loans and taxes, and the issue of war savings certificates for popular absorption has been vigorously begun. The bearing of these devices, notably of the certificates of indebtedness, upon the matter of inflation is an extremely difficult problem, certain aspects of which the present writer has undertaken in another connection to discuss. It is also interesting to note that the Comptroller of the Currency has wisely arranged that the forthcoming report of the conditions of the national banks, as of November 20, 1917, should make available certain much needed data as to subsciptions by and through banks to the second liberty loan, and as to the amount and quality of loans made by the banks on the security of liberty loan bonds. $-J . H . H$. 